\title{
ANALYSIS OF ISLAMIC MONETARY POLICY TRANSMISSION ON BUSINESS SECTOR AND MSME PERFORMANCE
}

\author{
Andri Soemitra ${ }^{1}$, Rifki Ismal ${ }^{2}$, Fuadi $^{3}$, Haris Al-Amin ${ }^{4}$, Syawal Harianto $^{5}$, Mukhlish M. Nur ${ }^{6}$, \\ Ahmad Fauzul Hakim ${ }^{7}$ \\ ${ }^{13456}$ State Islamic University of North Sumatra \\ ${ }^{2}$ Sekolah Tinggi Ilmu Ekonomi Islam Tazkia Bogor \\ ${ }^{7}$ Malikussaleh University \\ Email Corespondent : fuadi.msm@unimal.ac.id
}

\begin{abstract}
:
Study aims to analyze the form and impact of monetary policy transmission on the business world and MSMEs. The data used in the analysis related to the topic of the study were taken from various literatures, both from books and journal articles. The data from various sources were then analyzed using a literature review approach. Based on the results of the analysis, it was found that there were several forms of transmission of sharia monetary policy and other results found that transmission of sharia monetary policy had a positive and significant impact on the real and financial sectors in general and in particular had a positive and significant impact on the business world and MSMEs.
\end{abstract}

Keywords : Forms and Impacts of Monetary Policy Transmission 


\section{INTRODUCTION}

The international world has recognized that micro, small and medium enterprises (MSMEs) play a very important role in economic development and growth, not only in developing countries but also in developing countries. in developed countries. Developed countries such as the United States, Japan, France and the Netherlands have made the MSME sector a driving force for their country's economy, namely as a driver of economic growth, innovation and technological development (Tambunan, 2009).

The development of the Gross Domestic Product of MSMEs has shown an increase in the last 3 years. Based on data from the office of the Ministry of Cooperatives and MSMEs in 2011, the contribution of MSMEs to GDP was around 57.94 percent (table 2.6). In 2009, the contribution of MSMEs to GDP was around 56.53 percent. When viewed from the absorption of labor, MSMEs are able to absorb a much larger workforce than Large Enterprises. MSMEs are able to absorb about 97 percent of Indonesia's workforce, while large businesses are only able to absorb 3 percent of the workforce. (Ministry of Trade, 2013)

In fact, the development of the MSME sector in Indonesia is still faced with various problems. One of the fundamental problems faced is limited working capital and investment. Based on data from the Central Statistics Agency (BPS) in 2010, only 20.49 percent of micro and small businesses used loans and most of the loans came from individuals, not from formal financial institutions or banks. Their capital depends entirely on their own savings or informal sources such as family.

Seeing the above phenomenon, monetary policy is one of the macroeconomic policies that must be used by the central bank to achieve the ultimate goal of price stability, economic growth, employment opportunities, balance of payments balance. Price stability is a prerequisite for sustainable economic growth that can provide benefits for improving people's welfare. In order for monetary policy to achieve the goal of inflation, a pathway mechanism called the monetary policy transmission mechanism is needed. The transmission mechanism is a channel that connects monetary policy with the economy (Pohan, 2008). Basically the transmission mechanism of monetary policy is how to connect the monetary sector with the real sector.

The economic success of a country is largely determined by the precise determination of monetary policy. This policy was created based on a microeconomic response which was then managed at a macro level by policy makers. This policy-making step must be in accordance with the sharia scenario so that the economy that is expected to grow will get a blessing so that falah which is the ultimate goal of the economy is realized as the policy is taken. Finally, a literature review was taken in order to find answers to this essential concept of monetary policy. The ultimate goal of discussing sharia economic policy is to maintain and care for the economic stability of the country. The

effort to control the economic situation in a country is called monetary policy. The main thing is to regulate the stability of the value of money and the amount of money circulating in the homeland of each country. This macro policy is expected to be able to respond to micro economic growth so that real economic growth will be realized. Because monetary policy is very synonymous with money, the main task to understand the content of this paper is to understand the concept of money.

Money in Islam has a very limited definition, one of which is very forbidden is to make money as an object of transaction. Our success in interpreting money in an Islamic way will bring a unanimous understanding of Islamic economic policy as well. Given that the value of money is a reflection of price stability which has an impact on economic growth and development of the country as well as other effects, it is important that we examine the concept of money in Islam first.

Based on the description above, it can be formulated that the purpose of this research is to identify the form of transmission of double monetary policy in various parts of the world and Indonesia in particular through the conventional interest rate channel and through the sharia profit sharing/margin/fee channel and the relationship between the two and see the impact on business world and SMEs.

\section{LITERATURE REVIEW}

\section{Islamic Monetary Policy}

In a world dominated by capitalist (conventional) economics and finance, monetary policy that is widely known is monetary policy from a conventional perspective. Since the last 30 years, Islamic economics and finance have been gradually applied in various countries, singly or side by side with conventional ones. With the growing size and significance of Islamic economics and finance, monetary policy in an Islamic perspective also develops (Ascarya, 2012).

In countries that implement dual financial systems, such as Pakistan, Malaysia and Indonesia, the central bank must implement both conventional monetary policy and Islamic monetary policy to be 
able to effectively influence the overall macroeconomic situation (Ascarya, 2012).

In conventional economic literature, according to Djohanputro (2006), monetary policy is a government action in order to achieve macroeconomic management goals (output, prices and unemployment) by influencing the macro situation through the money market or in other words through the process of creating money or the money supply. . Likewise, Bofinger (2001) stated that monetary policy is manipulating of monetary instruments in order to achieve price stability, low unemployment and sustainable economic growth. The institution that is given the authority to implement monetary policy is usually in the form of a central bank or monetary authority of a country as a representative of the government.

In Islamic history, monetary policy is clearly implied in the life of the Prophet Muhammad and his companions Khulafau ar-Rosyidin. As was the case with Caliph Umar who had regulated the monetary sector with various regulations including: (1) Prohibiting all forms of action that had an impact on increasing volatility in purchasing power and instability in the value of money; (2) Prohibit counterfeiting of money; (3) Protecting inflation by giving advice to the public to invest their capital in the real sector, living simply and not living too much; (4) Printing dirhams in accordance with Islamic provisions, which is six daniq ((Ningsih, 2013).

Monetary policy is the rules and regulations issued by the monetary authority to control the money supply, inflation, and to maintain the economic stability of a country. This can be achieved in several ways, such as changes in interest rates, open market operations, and amendments to reserves for certain assets and deposits (Sholihin, 2013).In its implementation, monetary policy strategies are carried out differently in each country, according to the objectives to be achieved and the mechanism. transactions that apply to the country's economy.

Islamic monetary policy acts as a supporter of the real sector. To achieve this goal, money and banking institutions are the two most important parts that must be used to achieve the goal of achieving sharia monetary policy (Chapra, 1997). monetary aims to achieve Islamic socio-economics namely:

Broad economic welfare based on full employment with an optimum growth rate;

Socio-economic justice and equitable distribution of income and

welfare, one of which can be done with a good and correct zakat mechanism;
Stability of the value of money so that it really becomes a truly fair and stable medium of exchange.

Mobilization and investment of capital for productive economic development with a fair distribution system for all parties involved;

Deliver other services, such as primary and secondary markets to meet the need for noninflationary financing and finance for the government

\section{Islamic Monetary Policy Transmission}

In simple terms, the monetary policy transmission mechanism is a channel that connects monetary policy and the economy. The monetary transmission mechanism begins when the monetary authority or the central bank acts using monetary instruments in the implementation of monetary policy until the effect on economic activity is seen, directly or gradually. The impact of the monetary authority's actions on economic activity occurs through various channels, namely: money or direct channels, interest rate channels, credit, exchange rates, asset prices and expectations channels. (Pohan, 2008)

Transmission of monetary policy emerged since the emergence of a separate monetary authority from the fiscal authority. Monetary authority developed in line with the development of the central bank from the circulation bank (issuing fiat money) which was marked by the emergence of the Bank of England (BOE) in 1694 (Capie, 1994). Because paper money is inflatable (because it has no intrinsic value), the central bank's task is to develop, including regulating the amount of money in circulation to control currency values or inflation. This is not necessary when the money used is intrinsic money, such as gold dinars and silver dirhams during the Islamic caliphate. The last Islamic caliphate, the Ottoman dynasty in Turkey, collapsed in 1924 (Islahi, 2004).

In the era of the dominance of the conventional economy with paper money and its central bank until now, Islamic economics is developing in Muslim-majority countries in the midst of the paper money system and central bank. Therefore, the Islamic monetary system has also developed with its policies and transmission processes. One of the pioneers in developing contemporary Islamic monetary economic theory is Muhammad Umer Chapra (1985) with his book Towards a Just Monetary System. 
The setting of contemporary Islamic financial institutions is not much different from that of conventional financial institutions that have been established, so that many Islamic monetary policy instruments are similar to conventional monetary policy instruments. However, because the workings of Islamic monetary policy instruments have similarities and differences in principle with the workings of conventional monetary policy instruments, the transmission of Islamic monetary policy can be the same or different from the transmission of conventional monetary policy. Chapra (1985) does not specifically discuss the issue of the transmission of Islamic monetary policy. There is also no further development of Islamic monetary theory that mentions the transmission of Islamic monetary policy, including pass-through or its routes.

However, several empirical studies have begun to emerge to see the transmission of Islamic monetary policy with its characteristics. Sukmana and Kassim (2010) is an initial effort to find out the transmission of monetary policy in the financing channel through Malaysian Islamic banking to economic growth, which is formulated simply as follows.

$$
\mathrm{IPI}=\mathrm{f}(\mathrm{IF}, \mathrm{ID}, \mathrm{ONIGHT})
$$

Where IPI is the Industrial production index as a proxy for economic growth or output, IF is Islamic banking financing, ID is Islamic banking funding or third party funds/DPK, and ONIGHT is the overnight interest rate on the money market Interbank as an indicator of monetary policy

The same thing for the case of Indonesia has been carried out by Ascarya (2012) with the aim of knowing the transmission of monetary policy in the financing channel through Indonesian Islamic banking to the ultimate goal of monetary policy, namely economic growth and stability of the value of money, which is formulated in a simple as follows.

$$
\mathrm{IPI}=\mathrm{f}(\mathrm{IFIN}, \mathrm{IDEP}, \text { PUAS, SBIS })
$$

and

$$
\mathrm{CPI}=\mathrm{f}(\text { IFIN, IDEP, PUAS, SBIS })
$$

Where IPI is Industrial production index as a proxy for economic growth or output, CPI is Consumer price index as a proxy for inflation, IFIN is financing Sharia banking, IDEP is funding or third party funds/DPK Sharia banking, and PUAS is the one-day interest rate on the Islamic interbank money market, and SBIS is the yield on Sharia Bank Indonesia Certificates as an indicator of monetary policy.

In addition, Ayuniyyah, et al. (2010) examined the transmission of dual monetary policy in Indonesia in order to achieve the goal of economic growth, which can be formulated simply as follows.

IPI = f ( $\mathrm{n}$ IFIN, n CCRD, iIFIN, iCCRD, nIDEP, nCDEP, iIDEP, iCDEP, SBIS, SBI)

Where IPI is the Industrial production index as a proxy for economic growth or output, nIFIN is the amount of Islamic banking financing, nCCRD is the amount of credit conventional banking, iIFIN is the return on Sharia banking financing, iCCRD is the interest rate for conventional banking loans, nIDEP is the amount of funding or third party funds/DPK Syariah banking, nCDEP is the amount of funding or TPF for conventional banking, iIDEP is the return on TPF for Sharia banking, iCDEP is the yield on conventional banking deposits, SBIS is the yield on Sharia Bank Indonesia Certificates as an indicator of Sharia monetary policy, and SBI is the interest rate for Bank Indonesia Certificates as an indicator of conventional monetary policy.

Meanwhile, the Sharia pass-through policy rate has never been studied theoretically or empirically, to see the effectiveness of Sharia monetary policy. With this fact, the effectiveness of Sharia policy rate pass-through, can temporarily adopt the conventional interest rate pass-through theory, with equivalent modifications. As a start, the conventional interest rate pass-through model (Egert et al., 2006) can be modified to create a Sharia policy rate pass-through model. The initial equation (1) is modified to be as follows.

$$
i b r_{n, t}=\gamma_{0}+\gamma i m r_{n, t}
$$

Where ibr is the yield (funding or financing) determined by Islamic banks, 0 is the markup, and imr is the marginal cost price which is proxied by market return.

While the estimation equation, can follow de Bondt (2002) with modifications, so that it becomes as follows.

$$
\Delta i b r_{n, t}=\eta_{n}+\alpha \Delta i m_{t}-\beta\left(i b r_{n, t-1}-y i m r_{t-1}\right)+\varepsilon_{n, t}
$$


Where is a one-period pass-through parameter, while is a pass-through adjustment speed parameter. The first step is to calculate the residual from Equation 10 (ibrn,t-1- $\gamma$ imrt-1). The second stage is estimating Equation 11 by entering the residual (ibrn,t-1 - $\gamma$ imrt-1).

Asset yang dimiliki oleh perusahaan secara umum terdiri dari Asset tetap dan Aset Lancar. Asset tetap seringkali disebut sebagai "the earning asset" yaitu asset yang sesungguhnya menghasilkan pendapatan bagi perusahaan, oleh karenanya melalui asset tetap inilah yang memberikan dasar bagi "Earning Power" perusahaan. Ini berarti bahwa besar kecilnya laba sangat dipengaruhi oleh seberapa besar asset yang merupakan earning poweer yang dimiliki perusahaan (Helfert, 1997).

Berdasarkan pembahasan tersebut, maka hipotesis penelitian ini adalah:

H1: Assets growth berpengaruh terhadap profitabilitas perbankan yang Listing di bursa efek Indonesia (BEI)

\section{METHODOLOGY}

Method used in this research is literature study. Literature study in this research was conducted to study the definition of keywords, deepen the theory and concepts and identify variables related to the background and context of the research. (Petticrew \& Roberts, 2006). According to Woodward (2004) there are six types of literature according to the method of publication, each of which is surveyed separately. The six types of literature are: serial review; main journal; conference proceedings (excluding those published in major journals); books (excluding conference proceedings and review series); report; secondary service. The review method used in this literature study is a systematic literature review which is defined as a process to identify, assess and interpret all available research results to answer specific research questions.

\section{RESULT AND DISCUSSION}

Based on the results of the study, it was found that there are several forms of monetary policy transmission. Among them are research conducted by Fikri (2018), Sukmana \& Kassim (2010) and Abdul Rahim Abdul Rahman (2010). Fikri (2018) with the title Monetary Transmission Mechanism Under Dual Financial System In Indonesia: Credit-Financing Channel, generally states that based on the results of long-term ECM and VECM estimations, it shows that credit and financing channels are still relevant to be used in the post-sector development monetary transmission mechanism. finance and changes in monetary policy. However, it only has an impact on the economy and has no impact on inflation. While the ARDL estimation results show that there are no variables that affect the objectives of monetary policy, which means that credit and financing channels are considered to be getting weaker in the monetary transmission mechanism.

Sukmana \& Kassim (2010) with the title Roles of the Islamic banks in the monetary transmission process in Malaysia explained that based on the results of research conducted using Islamic financing, Islamic deposits, and overnight interest rate variables, it shows that Islamic bank financing and deposits play an important role. in the process of monetary transmission in the Malaysian economy. In particular, both Islamic savings and financing proved statistically significant in linking monetary policy indicators to real output.

Another research conducted by Abdul Rahim Abdul Rahman (2010) with the title Islamic finance, contagion effects, spillovers and monetary policy also states that Islamic finance offers various ethical schemes and instruments that can be developed and adapted for microfinance purposes. Comparatively, the qardhul hasan, murabahah, and ijarah schemes are relatively easy to manage and will guarantee the need for capital (qardhul hasan), equipment (murabahah) and rental equipment (ijarah) for prospective micro-entrepreneurs and the poor. Participatory schemes such as mudharabah and musyarakah, on the other hand, have great potential for microfinance purposes as these schemes can meet the risk-sharing needs of microentrepreneurs.

While research related to the impact of monetary policy transmission on the financial sector can be found in several studies conducted by Mahrous et.all (2020), Muhammad et al. (2017) and Narayan et al. (2012). Mahrous et.all (2020) in their research entitled The effect of monetary policy on credit risk: evidence from the MENA region countries concluded that there is a positive and significant relationship between monetary policy and credit risk to a certain extent 6.3. If the loan interest rate is higher than 6.3 , this increases credit risk in the banking sector, as an increase in loan interest rates burdens the borrower, and therefore 
bad loans and non-performing loans are more likely to occur.

Another important finding in this research is other research related to the impact of monetary policy on the market and the business world. This is as found in the research of Hussain \& Bilal (2020), Muhammad et al. (2017), Narayan et al. (2012), Jeon \& Wu (2013), Ascarya (2012) and Montes \& Bastos. In a study conducted by Hussain \& Bilal (2020) with the title Effect of monetary policy on bank risk: does market structure matter? done in China. In this study several independent variables have been used, including monetary policy (MP), natural interest rate gap between monetary policy (NGAP), the growth rate of the real gross domestic product (GDPGR), bank size (Size), liquidity (LIQ). and capitalization (CAP). In making estimates, the researcher uses the generalized method of movements (GMM) model proposed by Arellano and Bond. Based on the estimation results, it was found that bank-specific factors (size, liquidity and capitalization) did not significantly affect the risk-taking path. However, market structure has a stabilizing effect on monetary policy transmission and risk-taking pathways. Higher market forces weaken the risk-taking pathway of monetary policy transmission.

According to Muhammad et al. (2017) in a study entitled The Influence of Conventional and Islamic Monetary Instruments on Gross Domestic Product: An Empirical Investigation on Indonesia concluded that SBI has a significant positive effect on GDP in Indonesia. Meanwhile, Reverse Repo SUN, SBIS, and Reverse Repo SBSN have no significant effect on GDP. The results of this study can be used by the central bank to determine the portion of monetary policy in both Islamic and conventional banks to achieve optimal monetary policy objectives.

Narayan et al. (2012) in his research entitled An analysis of Fiji's monetary policy transmission that a monetary policy shock statistically significantly reduces output at first, but then output can recover to the level before the shock. Monetary policy shocks generate inflationary pressures, cause the Fijian currency to appreciate and reduce the demand for money. the impact of the nominal effective exchange rate (NEER) shock (appreciation) on real output and find that it leads to a statistically significant negative effect on real output.

According to Jeon \& Wu (2013) in their research entitled Foreign Banks, Monetary Policy,
And Crises: Evidence From Bank-Level Panel Data In Asia, it was found that foreign banks were slower than domestic banks in adjusting their loan growth to changes in host monetary policy. . This lag by foreign banks was found to be more pronounced in the recent 2008-2009 global crisis than in the 19971999 Asian regional crisis, indicating that the buffering/hampering effect of foreign banks on the effectiveness of the domestic monetary policy transmission mechanism became stronger in the recent global crisis. more recently coming from outside Asia than the regional crisis that exploded in Asia a decade earlier. The researcher also finds that the lower sensitivity of foreign banks than domestic banks to host monetary policy during the crisis period is heterogeneous, depending on factors such as the degree of adverse impact of the crisis on the parent bank, the scope of business operations by the parent bank, and the manner in which the bank operates. Foreigners enter the host banking market

Specifically, there are two studies that mention the impact of policies on the business world, namely research conducted by Ascarya (2012), Montes \& Bastos (2014) and Ramadhan \& Beik (2013). Ascarya (2012) said that the conventional transmission mechanism of conventional policy interest rates is all related to output and inflation, while Islamic policy interest rates are not related to output and inflation. In addition, shocks to interest rates, credit and interest rates between conventional banks have a negative and permanent impact on inflation and output, while PLS, financing and PLS among Islamic banks, as well as SBIS (Central Bank Sharia Certificate) as interest rate shocks in sharia policies have an impact positive and permanent on inflation and output. SBI (Central Bank Certificate) as a conventional policy has a positive impact on inflation and a negative impact on output.

The results of research by Montes \& Bastos (2014) with the title Economic policies, macroeconomic environment and entrepreneurs' expectations Evidence from Brazil show that monetary and fiscal policies and the credibility of the monetary regime affect economic activity with their impact on entrepreneurs' expectations.

Ramadhan \& Beik (2013) in his research entitled Analysis of the Effect of Islamic and Conventional Monetary Instruments on Fund Distribution to the Micro, Small and Medium Enterprises (MSME) Sector in Indonesia found that SBI and SBIS have a significant influence on credit and financing to MSMEs. When a monetary shock 
occurs, this study finds that MSME financing of Islamic banks can be recovered and stabilized better than conventional bank MSME loans. FEVD analysis shows that the impact of SBIS on MSME financing is greater than that of SBI.

\section{Discussion}

Based on several research findings related to several forms of monetary policy transmission, the above shows that there are several forms of Islamic monetary policy transmission, including the results of Fikri's research which states that two monetary transmissions are still relevant today, namely credit and financing channels. Meanwhile, Sukmana and Kasim proposed two different monetary transmissions, namely savings and sharia financing. Another research result from Abdul Rahim Abdul Rahman states that there are ethical schemes and instruments that can be developed and adapted for microfinance purposes. Among them are comparative schemes in the form of qardhul hasan, murabahah, and ijarah, murabahah and ijarah for prospective micro-entrepreneurs and the poor. Participatory schemes such as mudharabah and musharaka.

In research related to the impact of policy policies, it was found that the transmission of monetary policy had an impact on the financial sector. In terms of which can be found in several studies conducted by Mahrous et.all (2020), Muhammad et al. (2017) and Narayan et al. (2012). Based on the results of the analysis it was found that high interest rates will hinder developments in the real sector, market structure has a stabilizing effect on monetary policy transmission and risktaking pathways, Reverse Repo SUN, SBIS, and Reverse Repo SBSN have no significant effect on GDP, monetary policy has a significant effect on GDP. positive on the exchange rate and also on the handling of the monetary crisis.
In addition to several findings from the research which mention several forms and impacts of monetary policy transmission on the real sector, there are also several research findings which explicitly mention the impact and relationship of monetary policy transmission on the business world, especially the business world and Micro, Small and Medium Enterprises (MSMEs). ). Among them were stated by Ascarya, Montes \& Bastos and Ramadhan \& Beik, namely the SBIS (Central Bank Syariah Certificate) as a shock to the interest rate of sharia policy which has a positive and permanent impact on inflation and output, monetary and fiscal policy and the credibility of the monetary regime affects economic activity by the impact on entrepreneurs' expectations and MSME financing of Islamic banks can be recovered and stabilized better than conventional bank MSME loans.

Based on the findings and discussion behind it can be concluded that the transmission of Islamic monetary policy has several unique forms when compared to conventional monetary. Several forms of monetary policy transmission are believed to have a positive and significant impact on the macro and micro economy.

In completing the article, the author has received guidance from various parties, especially from the tutor for the courses in Monetary Economics and Islamic Banks and also from the Islamic Economics Undergraduate (S-3) Study Program at the State Islamic University of North Sumatra. So in this case, the author would like to thank Prof. Dr. Rifki Islam, Dr. Andri Soemitra, Dr. Sugianto and other parties whose names cannot be mentioned one by one.

\section{REFERENSI}

Ascarya, A. (2012). Alur Transmisi Dan Efektifitas Kebijakan Moneter Ganda Di Indonesia. Buletin Ekonomi Moneter Dan Perbankan, 14(3), 283-315. https://doi.org/10.21098/bemp.v14i3.360

Chapra, M. U. (1997). Al-Qur'an Menuju Sistem Moneter yang Adil Terj. oleh Lukman Hakim. Dhana Bakti Prima Yasa.

Fikri, R. J. (2018). Monetary Transmission Mechanism Under Dual Financial System In Indonesia: CreditFinancing Channel. 4(2), 251-278.

Hussain, M., \& Bilal, A. R. (2020). Effect of monetary policy on bank risk: does market structure matter? https://doi.org/10.1108/IJOEM-09-2019-0674

Jeon, B. N., \& Wu, J. (2013). Foreign Banks, Monetary Policy, And Crises: Evidence From Bank-Level 
Panel Data In Asia. In International Finance Review (Vol. 14, Issue 2013). Emerald Group Publishing Limited. https://doi.org/10.1108/S1569-3767(2013)0000014007

Mahrous, S. N., Samak, N., \& Abdelsalam, M. A. M. (2020). The effect of monetary policy on credit risk: evidence from the MENA region countries. Review of Economics and Political Science, 5(4), 289304. https://doi.org/10.1108/reps-07-2019-0099

Montes, G. C., \& Bastos, J. C. A. (2014). Economic policies, macroeconomic environment and entrepreneurs 'expectations Evidence from Brazil. https://doi.org/10.1108/01443581311283952

Muhammad, T. R., Cahyono, E. F., \& Widiastuti, T. (2017). The Influence of Conventional and Islamic Monetary Instruments on Gross Domestic Product : An Empirical The Influence of Conventional and Islamic Monetary Instruments on Gross Domestic Product: An Empirical Investigation on Indonesia. 2(2).

Narayan, P. K., Narayan, S., Mishra, S., \& Smyth, R. (2012). An analysis of Fiji's monetary policy transmission. 29(1), 52-69.

Petticrew, M., \& Roberts, H. (2006). Systematic Reviews in the Social Sciences.

Pohan, A., \& . (2008). Potret Kebijakan Moneter Indonesia: Seberapa Jauh Kebijakan Moneter Mewarnai Perekonomian Indonesia. PT. Rajagrafindo Persada.

Rahim Abdul Rahman, A. (2010). Islamic microfinance: An ethical alternative to poverty alleviation. Humanomics, 26(4), 284-295. https://doi.org/10.1108/08288661011090884

Ramadhan, M. M., \& Beik, I. S. (2013). Analisis Pengaruh Instrumen Moneter Syariah dan Konvensional Terhadap Penyaluran Dana ke Sektor Usaha Mikro Kecil dan Menengah ( UMKM ) di Indonesia Analysis of the Impact of Islamic and Conventional Monetary Instruments towards Financing of Micro , Small. Al-Muzara'ah, I(2), 175-190.

Sholihin, A. I. (2013). Buku pintar ekonomi syariah. Gramedia Pustaka Utama.

Sukmana, R., \& Kassim, S. H. (2010). Roles of the Islamic banks in the monetary transmission process in Malaysia. 3(1), 7-20. https://doi.org/10.1108/17538391011033834

Woodward, A. M. (2004). Review literature: characteristics, sources and output in 1972 